\title{
Mídia e cidadania: visões díspares dos protestos de 2013
}

DOI: $10.1590 / 1809-58442015117$

\section{Eduardo Ritter}

(Pontifícia Universidade Católica do Rio Grande do Sul, Faculdade de Artes e Comunicação,

Programa de Pós-Graduação em Comunicação Social.

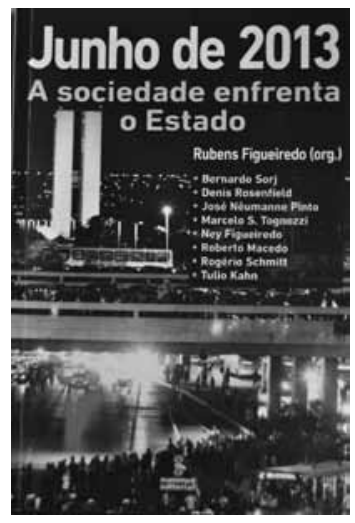
Porto Alegre - RS, Brasil)

FIGUEIREDO, Rubens (org.). Junho de 2013 - A sociedade enfrenta o Estado. São Paulo: Summus, 2014. 159p.

$\mathrm{P}$ raticamente, tudo na vida tem altos e baixos. Em alguns momentos obtemos sucesso na carreira, nos estudos, nas obrigações domésticas, nos esportes, na saúde etc. No entanto, com o passar dos anos é inevitável os momentos de crise, de frustração, de perdas, de doença e de infelicidades. Pois a obra Junho de 2013 - A sociedade enfrenta o Estado, organizada por Rubens Figueiredo, conseguiu reunir altos e baixos em um único livro. Tudo porque a obra é uma coletânea com nove artigos escritos por especialistas de diversas áreas para analisar os protestos sociais que ocorreram no Brasil em junho de 2013.

O livro pode ser pensado a partir de duas perspectivas. Na primeira, é possível fazermos uma divisão entre os artigos que consideraram o fator midiático, em especial as redes sociais, como algo central; e outros que, ou por falta de interesse ou 
de competência, não fazem menção à importância da Web nos protestos. Já a segunda perspectiva vale ser registrada no sentido da "crítica da crítica", defendida por José Luiz Braga em seu livro quase homônimo A sociedade enfrenta sua mídia (São Paulo, Paulus, 2006). Nesse segundo olhar, é percebida uma paixão político partidária, que pode ser justificada se atentarmos para a biografia de alguns dos autores - fato esse que, se não compromete a obra na sua íntegra, coloca em risco a credibilidade de algumas das análises. Comecemos, no entanto, pela primeira perspectiva.

Os dois artigos que tratam em primeiro plano o papel das tecnologias nos protestos: "A força das redes sociais", de Marcelo S. Tognozzi, e "Entre o local e o Glocal", de Bernardo Sorj. Esses dois artigos valem a leitura do livro. No primeiro, Tognozzi não desperdiça uma linha com especulações partidárias ou críticas raivosas. $\mathrm{O}$ autor apresenta dados e interpretações interessantes como, por exemplo, uma pesquisa feita em período bem anterior ao dos protestos, de junho de 2011, quando já havia sido registrado que $71 \%$ dos jovens consideravam a internet a melhor ferramenta política. Outro ponto interessante é o número de compartilhamentos e acessos feitos de mensagens e vídeos divulgados pelas redes sociais, eliminando a necessidade do reconhecimento dos grandes conglomerados de Comunicação para ter representatividade. Um exemplo disso são os recordes de acessos no Youtube. Felipe Neto, um carioca de 25 anos que desabafa sobre a situação do país, por exemplo, teve o seu vídeo assistido por 3,6 milhões de pessoas.

Em seu texto, Tognozzi também faz um resgate de outros movimentos sociais que ocorreram no mundo nos últimos anos, como os da Ucrânia (2004), França (2005), Primavera Árabe (2011), dentre outros. Então, ele chega a um dos principais pontos do artigo - e do livro - que é a disparidade entre a população, que está cada vez mais imersa nas redes sociais, e a visão dos políticos, além da perda da legitimidade das instituições e dos partidos tradicionais. A denominação de "políticos 1.0" é perfeita, pois muitos deles ainda ignoram a representatividade dos conteúdos que circulam na Web - como se robôs estivessem atrás dos 
computadores, e não pessoas que votam, vão às ruas, conversam, pensam, criticam, namoram etc. "Os protestos de junho de 2013 deixaram os políticos e seus partidos fora da festa, porque ficou evidente sua total desconexão com as ruas" (p.82). Além disso, a grande mídia também teve um papel de figurante, afinal, nenhum veículo tradicional convocou a população para ir às ruas.

$\mathrm{O}$ outro artigo que aborda em primeiro plano as novas tecnologias e a Comunicação é o de Bernardo Sorj. O autor analisa, por exemplo, o declínio dos grupos reivindicatórios tradicionais, como sindicatos, associações, agremiações estudantis e partidos políticos, que ocorre paralelamente ao surgimento de um novo espaço público virtual, que funciona de forma viral, reunindo milhares de pessoas em torno de ideais, que anteriormente só eram assumidas pelas organizações. Um ponto importante do artigo de Sorj é a visão que ele apresenta de que o virtual não substitui o real em sua totalidade: "dois milhões de assinaturas virtuais, no melhor dos casos, vira notícias de jornal, ao passo que dois milhões de pessoas nas ruas podem derrubar governos" (p.91). Aliás, outra ótima percepção do autor é relatar que a grande descoberta dos protestos de 2013 foi a rua, e não a internet - afinal, os jovens já estão tão familiarizados com o mundo virtual, que o outside, às vezes, pode causar estranheza.

Assim como os dois artigos citados, os textos "A segurança pública e as manifestações", de Tulio Kahn, "Entre o libertário e a usurpação", de Denis Resenfield, e "Os jovens na população brasileira: uma breve análise política”, de Rogério Schmitt, destacam-se não só por levar para as suas temáticas a questão das tecnologias e da Comunicação, como também por assumirem que os protestos não foram algo partidário, pró ou contra governo, mas sim, que os manifestantes queriam, antes de tudo, um país melhor com outro sistema político, diferente do atual, que está defasado e que não inspira confiança. Em sentido completamente oposto a essas análises, aparecem os demais textos.

Capítulos como "A espiral do silêncio e a escalada da insatisfação", do organizador Rubens Figueiredo, pecam pelo fato de que o autor deixou de perder o controle das suas 
passionalidades políticas. Figueiredo, como alguns dos outros analistas da obra que tomam partido nas discussões, trabalhou diretamente com o ex-presidente Fernando Henrique Cardoso. Talvez por esse motivo ele encarna o discurso de que a era PréLula foi perfeita e a pós-Lula foi um inferno. $\mathrm{O}$ autor também usa a teoria da psicóloga alemã Elisabeth Noelle-Neumann intitulada "Espiral do Silêncio" de maneira superficial e com um olhar esquizofrênico que mereceria considerações a parte. $\bigcirc$ mesmo erro de deixar a paixão político-partidária tomar conta é percebido nos textos "Uma visão econômica e política dos protestos juninos", de Roberto Macedo e "Os empresários e os movimentos de rua", de Ney Figueiredo. Já José Nêumanne Pinto ultrapassou os limites da paixão política para empilhar chavões tomados de ódio. Em algo que só pode ser interpretado como um bloqueio intelectual, ele encerra o artigo com um lamentável: "quem pode mais chora menos" (p.114).

Em meio a altos e baixos, no balanço dos nove artigos, os cinco primeiramente mencionados fazem jus a intencionalidade da obra, que, diga-se de passagem, poderia ser melhor. Enquanto que os outros quatro fazem exatamente aquilo o que os protestantes abominavam: apresentam olhares cegos de amor pelos partidos políticos e formas de governo tradicionais.

\section{Eduardo Ritter (autor da resenha)}

Jornalista, mestre e doutorando do Programa de Pós-Graduação em Comunicação Social da Pontifícia Universidade Católica do Rio Grande do Sul (PUC-RS), com período sanduíche de um ano na New York University (NYU), Nova York-EUA. Bolsista Capes/Prosup. E-mail: rittergaucho@ hotmail.com 